\title{
Semantic transfers in the domain of FOODSTUFFS
}

\author{
Aleksandra Zofia Kowalczyk \\ John Paul II Catholic University of Lublin, Poland
}

\begin{abstract}
In recent literature scholars have worked out a number of new categories of meaning development such as zoosemy, plantosemy and foodsemy. This paper focuses on the mechanism of foodsemy, a new category of metaphorical extension proposed by Kleparski (2008), and in particular on the cases of metaphorical extension that are targeted at human beings and their various qualities. Most frequently, the process discussed here involves the projection of attributive features and values, sometimes positive, yet most frequently negative ones, associated with members of the macrocategory FOODSTUFFS onto the macrocategory HUMAN BEING. The purpose here is to outline a limited number of metaphorical transfers involved in the conceptual macrocategory FOODSTUFFS targeted at such subcategories of the microcatergory FEMALE HUMAN BEING as ATTRACTIVE FEMALE HUMAN BEING, IMMORAL FEMALE HUMAN BEING and FEMALE BREASTS. For some language users it may sound somewhat unnatural, and hence unacceptable, to name a female person mutton with the intended metaphorical sense 'a prostitute', tomato applied in the transferred sense 'attractive, but not a very wise female' or peach, which denotes an 'attractive female, especially in American English'. However, cases of foodsemy are nothing else, but instances of metaphorical conceptualizations, which are considered to be pervasive, unconscious and automatic. They are also universal, though different lexical items in different languages may acquire different metaphorical senses.
\end{abstract}

Keywords: food metaphor, foodsemy, anthropomorphization, female names

\section{Introduction: Language as a rule-governed system}

Traditionally, language has frequently been compared to an organism consisting of various subsystems each of which functions by its own rules and regulations. In order to function, every organism must be regulated by well-defined and self-repeating rules which make it go on and perform various functions and in the case of language the main function to fulfil is communication. As in the case of every system, the functioning of the language system may be either undisturbed or go out of balance, or worse still, come to a halt altogether. This may be brought about by either external or internal factors, and these may be accounted for either synchronically or diachronically.

First, when we consider the latter we may give the example of the importance of borrowing in the history of English and many other currently used languages. In the history of English the process of borrowing may be said to have had a great impact on the structure of the language at 
an early stage (Kleparski 2012). On the contrary, English is making a great impact on the structure of Polish now, with more than ten thousand lexical items being currently present in the vocabulary of Polish (Mańczak-Wohlfeld 1992). In short, as a result of borrowing many irregular, and - from the point of view of the Polish language system - anomalous structures appear, and this number includes both simple lexical items and the previously unknown senses but also complex idiomatic expressions. For example, let us consider the novel application of the Polish verb dedykować which until recently was used in the sense 'to dedicate a book/poem/song (to someone)', and which under the influence of the semantics of English dedicate has recently acquired the sense 'to mean, to intend for'. Obviously, in this case, one may talk about semantic borrowing rather than lexical borrowing. One may hypothesize that the anomalous character of this innovation will most likely disappear into thin air, and in time will become perfectly acceptable.

To pursue the issue further, in the sphere of phraseology there are countless examples of fixed expressions that seem to be completely unmotivated and hence either rationally or culturally anomalous. Take, for example, the English expression to kick the bucket, which is a euphemism for to die, and - etymologically speaking - it derives from either the suicide's kicking away the bucket on which he/she is standing, in order to hang him/herself, or from the bucket beam on which pigs were hung after being slaughtered. The odd post mortem spasms would lead to the 'bucket' being kicked (see Cassell's Dictionary of Word and Phrase Origins).

In the remaining part of this paper, we shall focus our attention on the figurative transfers resulting from foodsemy. The transfers in question have been present at various stages of the development of English and the mechanism has affected various sectors of the English vocabulary. The body of cases of foodsemy mostly related to the concept FEMALE HUMAN BEING have been extracted from such lexicographic sources as Oxford English Dictionary, The Routledge Dictionary of Modern American Slang and Unconventional English, Concise New Partridge Dictionary of Slang and Unconventional English, Green's Dictionary of Slang and The Slang of Sin. Some examples are quoted after Kleparski $(2008,2012)$. Online sources, such as The Probert Encyclopedia of Slang, Online Slang Dictionary and Urban Dictionary, and web searches also played a crucial part as they offer numerous up-to-date examples of foodsemy.

\section{Food-based metaphorical transfers}

Recent studies of metaphor have shed new light on the nature of the metaphorization processes. In particular, the last decades of the $20^{\text {th }}$ century and the beginning of the $21^{\text {st }}$ century have been marked by a much intensified rise in interest in the study of metaphor, which is one of the main targets of present day semantic research in both Poland and abroad. Let us mention here such works as Lakoff (1987, 1993), Lakoff and Johnson (1980), Lakoff and Turner (1989), Langacker (1987, 2000), Kövecses (2000), Geeraerts (2010), and in the Polish tradition Kleparski (1990, 1997), Krzeszowski (1991, 2003), Szwedek (2000, 2004), Kiełtyka (2009), Cymbalista and Kleparski (2013). The pioneering work by Lakoff and Johnson (1980) is of great importance to cognitive semantics as it voices and substantiates the view that metaphors are not poetic devices restricted to literary and highly sophisticated language. On the other hand, the scholars claim 
that metaphor is a matter of ordinary language and everyday life and activities as metaphors "govern our everyday functioning, down to the most mundane details. Our concepts structure what we perceive, how we get round in the world, and how we relate to other people. Our conceptual system thus plays a central role in defining our everyday realities" (Lakoff and Johnson 1980: 3). Consequently, our conceptual system is metaphorical and, additionally, subconscious in nature.

The fundamental works, such as Lakoff (1987, 1993), Lakoff and Johnson (1980), Lakoff and Turner (1989) have laid foundations for a number of case-specific studies in various natural languages. At the same time new categories of metaphorical transfers, though known and evidenced for a long time, have been named and renamed. Here, one must mention such longrecognized types of metaphorical change as zoosemy, but also new well-defined and richly documented types of semantic metaphorical transfers as plantosemy, and - in particular - the type of metaphorical change that with time became generally acknowledged as foodsemy.

The term foodsemy was first used a decade ago in Kleparski (2008), who discussed metaphorical transfers where the source domain is formed by lexical items from the source domain FOODSTUFFS and the target domain is the macrocategory HUMAN BEING. The mechanism proves to be highly productive in various languages. In English it affects a variety of grammatical categories including fixed phrases, idiomatic expressions or individual nouns, adjectives and verbs. On the largest scale, foodsemic transfers affect nouns, (e.g. English meat > 'person viewed as sexual object', cheesecake > 'attractive girl'), but it is possible to trace foodsemic adjectives (e.g. English porky > 'fat, obese', cheesy > 'of poor quality'), verbs (to cream off $>$ 'to take the best part of something', to salt away > 'to save money'). ${ }^{1}$

As far as the category of nouns is concerned, many foodsemic metaphors are targeted at the category HUMAN BEING, and a great number of such metaphorical uses are channelled through the sphere of taste. For example, one may quote the following cases of foodsemic metaphor: Slovak cukrik 'candy' > 'young, attractive girl', Italian zucchero 'sugar' > 'kind, pleasant or handsome person', fico 'fig' > 'beautiful, handsome person'. Further examples can be found in English cheesecake, cupcake, cream-puff, sweet meat, bun, biscuit, honey-bunny, sugar pie, peach, American English sugar baby, sugar pie, arm candy and shoulder candy > 'young, attractive lady', apple pie > 'dear, beloved person'. While analysing the body of data, one distinguishes positively loaded attributive values, such as $<$ PLEASANT $>,<$ DEAR $>$, $<$ HANDSOME $>$ or $<$ BEAUTIFUL $>$ (the English examples taken from Kowalczyk 2015a).

At the same time, Kleparski (2008) provides us with numerous examples of foodsemic transfers having their basis in visual resemblance of some foodstuffs which underlie metaphorical shifts. Here, one may quote the cases of English pear > 'pear-shaped person, especially woman', Polish grucha 'pear' > 'penis' or 'ill-shaped female'. Hence, the concept of

\footnotetext{
This applies to various natural languages and in Polish the process may be illustrated by metaphorical meanings of such denominal verbs as kiełbasić (kiełbasa 'sausage') > 'to fail to do something', chrzanić (chrzan 'horseradish') > 'to talk rubbish', cukrować (cukier 'sugar') > 'to pander', as well as idiomatic expressions and proverbs (e.g. English a piece of cake > 'something easy to do' or to be as cool as a cucumber >'to stay calm in stressful situations'). The same process affects idiomatic expressions, such as Don't put all your eggs in one basket standing for 'don't depend on a single plan or action or person for success', to be in a soup/to be in jam meaning 'to be in trouble'.
} 
mental blockishness and stupidity is realized by the presence of such attributive features as SIZE: <LARGE > and SHAPE: <ROUND>. Italian anchovy 'a small, marine, herring-like fish' > 'a very thin girl'. Spanish albondiga 'meatball' stands for a person who is 'extremely fat, obese'. Meaning transfers given above can be explained because in many cases of foodsemic metaphorization processes one may find conceptual values that bridge the primarily, historically original sense on the one hand and the figurative sense on the other. Take, for example, the metaphorical sense of Polish grucha 'pear-shaped or downwards unshapely woman'.

In what follows we shall focus our attention on metaphorical foodsemic transfers that are targeted at two categories, that is macrocategory FEMALE HUMAN BEING and microcategory FEMALE BODY PARTS. Kleparski's idea has been tested against an extensive body of data drawn from numerous dictionaries. We bring to light new examples of the phenomenon in question.

\section{Foodsemic transfers targeted at the macrocategory FEMALE HUMAN BEING}

According to Cutierrez-Rivas (2011: 7) "metaphors derive in some cases from analogies, since it is relatively easy and spontaneous for humans to create such by watching the ordinary things common to them and the world that surrounds them". Metaphors can become so ingrained in a culture that nobody questions the meaning behind them. In consequence, they are a perfect tool for introducing various topics and notions, such as gender differences, for example. Both woman and the female body are frequently pictured and viewed from a metaphorical perspective as food that can be eaten. In these metaphors of consumption women are usually eaten (or devoured), rather than consume food themselves. Cutierrez-Rivas (2011: 9) claims that "women are mere products to be consumed, enjoyed and discarded."

Let us now focus on those English foodsemic transfers in which food and food-related lexical items come to be employed to conceptualize and encode those senses that are related to various positions within the macrocategory FEMALE HUMAN BEING. Kleparski (1997) carries out an in-depth study of historical synonyms of girl/young woman, yet strangely enough there are almost no cases of foodsemy. The study published by Grygiel (2008) shows that in the history of English there have been very few foodsemic developments related variously to the conceptual category MALE HUMAN BEING. Because of the abundance of examples of cases of foodsemic uses in present day English one is tempted to conclude that the mechanism of food metaphor has become productive very recently. Let us start with tabulating the language data that have been collected for the purpose of this analysis. The results of our dictionary and web searches are presented below. Section 3.1. contains the set of lexical items where the names of foodstuffs are used with reference to attractive females. Section 3.2. presents the negative picture of a woman viewed foodsemically as immoral. Section 3.3. focuses on lexical items used in the sense 'female breasts'. Due to space limitations, each table contains only one example of use of a given lexical item in context. There is also information about the source or sources of metaphorical meanings. The example comes from the dictionary which comes first on the list. 


\subsection{ATTRACTIVE FEMALE HUMAN BEING viewed foodsemically}

Let us now focus on those English transfers in which food and food-related lexical items come to be employed to encode senses related to the conceptual microcategory ATTRACTIVE FEMALE HUMAN BEING.

Table 1: FOODSTUFFS for ATTRACTIVE FEMALE HUMAN BEING

\begin{tabular}{|c|c|c|c|}
\hline & Lexical item & Sense & Example of use or the source \\
\hline 1. & bun & 'attractive girl with a nice body' & $\begin{array}{l}\text { She's a little bun, isn't she? [...] A little bun. A honey } \\
\text { bun. Little raisin eyes. Sweet icing lips. } \\
\text { Green's Dictionary of Slang, Urban Dictionary, Concise } \\
\text { New Partridge Dictionary of Slang and Unconventional } \\
\text { English }\end{array}$ \\
\hline 2. & biscuit & 'good looking woman' & $\begin{array}{l}\text { Urban Dictionary, The Routledge Dictionary of Modern } \\
\text { American Slang and Unconventional English, Green's } \\
\text { Dictionary of Slang }\end{array}$ \\
\hline 3. & cheesecake & 'attractive female' & $\begin{array}{l}\text { OED, Urban Dictionary, Concise New Partridge } \\
\text { Dictionary of Slang and Unconventional English, The } \\
\text { Routledge Dictionary of Modern American Slang and } \\
\text { Unconventional English, Green's Dictionary of Slang }\end{array}$ \\
\hline 4. & cookie & $\begin{array}{l}\text { 'woman, esp. attractive, } \\
\text { seductive girl' }\end{array}$ & $\begin{array}{l}\text { OED, Concise New Partridge Dictionary of Slang and } \\
\text { Unconventional English, Urban Dictionary, Green's } \\
\text { Dictionary of Slang }\end{array}$ \\
\hline 5. & creampuff & 'attractive, delicate female' & $\begin{array}{l}\text { Concise New Partridge Dictionary of Slang and } \\
\text { Unconventional English, The Routledge Dictionary of } \\
\text { Modern American Slang and Unconventional English, } \\
\text { Urban Dictionary }\end{array}$ \\
\hline 6. & cupcake & 'cute, adorable girl' & $\begin{array}{l}\text { The Routledge Dictionary of Modern American Slang } \\
\text { and Unconventional English, Urban Dictionary, } \\
\text { Green's Dictionary of Slang }\end{array}$ \\
\hline 7. & sweet meat & 'young, attractive female' & Urban Dictionary, Green's Dictionary of Slang \\
\hline 8. & arm candy & $\begin{array}{l}\text { 'remarkably attractive female, } \\
\text { often female companion } \\
\text { escorting a more celebrated or } \\
\text { influential person at a social } \\
\text { event' }\end{array}$ & $\begin{array}{l}\text { The Routledge Dictionary of Modern American Slang } \\
\text { and Unconventional English, Urban Dictionary, } \\
\text { Green's Dictionary of Slang }\end{array}$ \\
\hline 9. & honey-bunny & 'young, pretty girl' & Urban Dictionary; the entry based on Pulp Fiction \\
\hline 10. & shoulder candy & 'young, pretty girl' & Urban Dictionary \\
\hline 11. & sugar baby & 'young, pretty girl' & Urban Dictionary, Green's Dictionary of Slang \\
\hline 12. & sugar pie & $\begin{array}{l}\text { 'young, pretty girl, a term of } \\
\text { endearment' }\end{array}$ & Urban Dictionary \\
\hline 13. & toast & 'skinny girl with large breasts' & Urban Dictionary \\
\hline 14. & peach & $\begin{array}{l}\text { 'attractive, young female, } \\
\text { especially particularly desirable } \\
\text { one' }\end{array}$ & $\begin{array}{l}\text { OED, Urban Dictionary, Concise New Partridge } \\
\text { Dictionary of Slang and Unconventional English, The } \\
\text { Routledge Dictionary of Modern American Slang and } \\
\text { Unconventional English, Green's Dictionary of Slang }\end{array}$ \\
\hline 15. & tomato & $\begin{array}{l}\text { 'attractive, but not very wise } \\
\text { young girl' }\end{array}$ & $\begin{array}{l}\text { OED, The Routledge Dictionary of Modern American } \\
\text { Slang and Unconventional English, Urban Dictionary, } \\
\text { Green's Dictionary of Slang }\end{array}$ \\
\hline
\end{tabular}




\begin{tabular}{|c|c|c|c|}
\hline 16. & milk & 'gorgeous white female' & Urban Dictionary \\
\hline 17. & ham & $\begin{array}{l}\text { 'beautiful, cute, sexy and good- } \\
\text { looking girl' }\end{array}$ & $\begin{array}{l}\text { The Routledge Dictionary of Modern American Slang } \\
\text { and Unconventional English, Urban Dictionary }\end{array}$ \\
\hline 18. & salt & 'extremely attractive female' & $\begin{array}{l}\text { Concise New Partridge Dictionary of Slang and } \\
\text { Unconventional English, Urban Dictionary }\end{array}$ \\
\hline 19. & pepper & $\begin{array}{l}\text { 'extremely attractive young } \\
\text { female' }\end{array}$ & $\begin{array}{l}\text { Concise New Partridge Dictionary of Slang and } \\
\text { Unconventional English, Urban Dictionary, Green's } \\
\text { Dictionary of Slang }\end{array}$ \\
\hline 20. & sauce & 'attractive female' & Urban Dictionary \\
\hline 21. & dish & 'attractive woman' & $\begin{array}{l}\text { Concise New Partridge Dictionary of Slang and } \\
\text { Unconventional English, The Routledge Dictionary of } \\
\text { Modern American Slang and Unconventional English, } \\
\text { Urban Dictionary, Green's Dictionary of Slang }\end{array}$ \\
\hline 22. & snack & 'attractive female' & $\begin{array}{l}\text { Concise New Partridge Dictionary of Slang and } \\
\text { Unconventional English, The Routledge Dictionary of } \\
\text { Modern American Slang and Unconventional English, } \\
\text { Urban Dictionary }\end{array}$ \\
\hline
\end{tabular}

From the point of view of their morphological build-up the set of lexical items contained in the above table features words of various morphological status. Simple lexical items (dish, tomato, salt, pepper, milk, cookie, bun, biscuit, toast, sauce, ham, snack, peach) slightly outnumber complex ones (cheesecake, cupcake, arm candy, cream puff, sweet meat, honeybunny, sugar pie, shoulder candy, sugar baby).

The data collected here provides evidence that the values presupposed for the DOMAIN OF TASTE [...] are most frequently responsible for the foodsemic transfers between the source domain FOODSTUFFS and the macrocategory FEMALE HUMAN BEING. This is most frequently realized through the metaphorical transfer of lexical items that in their primary sense refer to substances that are sweet per se (biscuit, cookie, sweet meat, cream puff, cheesecake, cupcake), but also types of fruit that are definitely on the sweet side (peach), and most abundantly by those foodstuffs that are on the sweet side, such as sugar or honey (sugar baby, sugar pie, honey-bunny, shoulder candy, arm candy). Likewise, various elements of meal/type of meal which may be said to be neutral with respect to the specification of taste may be found here (dish, sauce, snack). Additionally, and - in many cases somewhat surprisingly - seasoning substances (salt, pepper), that are also conceptually linked to the DOMAIN OF TASTE [...] are also present here. Last but not least, dairy products also serve as the source domain for foodsemic transfers in English (milk, cheesecake). However, the material in Table 1 above escapes any major generalization because there are some cases of foodsemic transfer that involve those lexical items whose semantics in no way contains elements of sweetness but rather sense sensations that are contrary to the concept of sweetness (ham, tomato). Nevertheless, in the majority of foodsemic developments related to the conceptual microcategory ATTRACTIVE FEMALE HUMAN BEING the possible general metaphorical path that may be formulated is < SWEETNESS IS PERCEIVED AS POSITIVE $>$. The overall and pervasive schema visible in the material discussed here has been so far formulated as <FEMALE HUMAN BEING IS FOOD/A FOOD ITEM>. This category may be branched further and in effect we arrive at the following set of more specific ones, namely: <ATTRACTIVE FEMALE HUMAN BEING IS PERCEIVED AS A FOOD 


\section{ITEM>, <ATTRACTIVE FEMALE HUMAN BEING IS PERCEIVED AS A SWEET FOOD ITEM $>$, <ATTRACTIVE FEMALE HUMAN BEING IS PERCEIVED AS A TASTY FOOD ITEM $>,<$ ATTRACTIVE FEMALE HUMAN BEING IS PERCEIVED AS FRUIT $>$.}

\subsection{IMMORAL FEMALE HUMAN BEING viewed foodsemically}

Table 2 given below presents figurative extensions of food-related lexical items that are secondarily related to the conceptual microcategory IMMORAL FEMALE HUMAN BEING which may be viewed as being conceptually embedded within the limits of the macrocategory FEMALE HUMAN BEING.

Table 2: FOODSTUFFS for IMMORAL FEMALE HUMAN BEING

\begin{tabular}{|c|c|c|c|}
\hline & Lexical item & Sense & Example of use or the source \\
\hline \multirow[t]{2}{*}{1.} & buttered bun & $\begin{array}{l}\text { 'sexually available woman', } \\
\text { 'prostitute' }\end{array}$ & $\begin{array}{l}\text { Two pretty lads, old Priam's sons, / Both very } \\
\text { fond of butter'd buns. }\end{array}$ \\
\hline & & & $\begin{array}{l}\text { Green's Dictionary of Slang, Concise New } \\
\text { Partridge Dictionary of Slang and } \\
\text { Unconventional English }\end{array}$ \\
\hline 2. & crumpet & 'desirable woman' & $\begin{array}{l}\text { OED, Urban Dictionary, Concise New Partridge } \\
\text { Dictionary of Slang and Unconventional } \\
\text { English, Urban Dictionary, Green's Dictionary } \\
\text { of Slang }\end{array}$ \\
\hline 3. & tart & 'female of immoral character' & $\begin{array}{l}\text { OED, Urban Dictionary, Concise New Partridge } \\
\text { Dictionary of Slang and Unconventional } \\
\text { English, Urban Dictionary, Green's Dictionary } \\
\text { of Slang, Green's Dictionary of Slang }\end{array}$ \\
\hline 4. & tartlet & $\begin{array}{l}\text { 'young woman of immoral } \\
\text { character' }\end{array}$ & OED, Urban Dictionary \\
\hline 5. & marmalade-madam & 'strumpet' & $O E D$ \\
\hline 6. & strawberry & $\begin{array}{l}\text { 'a female who in exchange for drugs } \\
\text { will have sex with anybody that can } \\
\text { provide drugs for her' }\end{array}$ & $\begin{array}{l}\text { Concise New Partridge Dictionary of Slang and } \\
\text { Unconventional English, Urban Dictionary, } \\
\text { Green's Dictionary of Slang }\end{array}$ \\
\hline 7. & meat & 'prostitute' & $\begin{array}{l}\text { OED, Urban Dictionary, Green's Dictionary of } \\
\text { Slang }\end{array}$ \\
\hline 8. & mutton & 'prostitute' & $\begin{array}{l}\text { OED, Urban Dictionary, Green's Dictionary of } \\
\text { Slang }\end{array}$ \\
\hline 9. & laced mutton & 'prostitute' & OED, British National Corpus \\
\hline 10. & veal & $\begin{array}{l}\text { 'young female, referring to a girl } \\
\text { younger than the interested male' }\end{array}$ & Urban Dictionary, Green's Dictionary of Slang \\
\hline 11. & sandwich & 'prostitute' & Urban Dictionary \\
\hline
\end{tabular}

As the data given in Table 2 shows, the majority of foodsemic transfers have affected those vocabulary items that are primarily related to meat and meat products. While analysing the data, we observe the presence of a variety of connotations associated with variously understood sexuality, or what are considered to be distortions of sexuality. The number of cases that have been tabulated confirms the fact that meat-based foodsemy is a highly productive mechanism 
(meat, a bit of meat, hot meat, veal, mutton, laced mutton, hot mutton, hot beef). Let us point to the fact that also in Polish we have a number of diminutive forms for meat-related lexical items that are used in reference to female sexual partners, e.g. mięsko 'meat. dim', cielęcinka 'veal. dim', wołowinka 'beef. dim', especially 'attractive and sexually available woman'. It is evident from the cases discussed above that one may speak here of a sexuality-oriented conceptualization of meat products, not only in English, but also in other languages. Metaphorical transfers of these meat-related words evidently follow the path of development $<$ SEXUAL USE OF A PERSON IS CONSUMPTION>, which may in fact be viewed as a case of mechanism of joint operation of metaphor and metonymy in the sense of Ruiz de Mendoza (1997). ${ }^{2}$

Apart from the most numerous cases of metaphorical developments involving names of meat products, we observe examples of meaning transfers of bakery terms (tart, tartlet, crumpet, buttered bun), dish type (sandwich), fruit (strawberry) and several of those involve a sweet substance, such as jam or marmalade (marmalade-madam, a bit of jam). The attributive value $<$ SWEET $>$ may be responsible for the application of the foodsemic metaphor, frequently yielding positively loaded semantic novelties. Generally speaking, the main paths of development operating in the category IMMORAL FEMALE HUMAN BEING are: <IMMORAL FEMALE HUMAN BEING IS PERCEIVED AS A SWEET FOOD ITEM $>$ and $<$ IMMORAL FEMALE HUMAN BEING IS PERCEIVED AS MEAT/A KIND OF MEAT >.

As for the morphological status of the lexical items that have undergone foodsemic transfers, there are altogether eleven examples of metaphorical transfers tabulated above where food products came to be applied in the sense 'immoral female human being'. We observe that compounds are less numerous than simple nouns. The body of morphologically complex items is represented by such complex nominal formations as laced mutton, marmalade madam, buttered bun. The remaining lexical items employed foodsemically are simplex words, such as tart, tartlet, mutton, sandwich, strawberry, crumpet, meat, veal.

At a glance, the semantic development of foodsemic items belonging to the category IMMORAL FEMALE HUMAN BEING enumerated in this section, have acquired various evaluatively loaded elements. These attributive values are (IMMORAL), (PROMISCUOUS), (UNACCEPTABLE), (DESPISED), (CONTEMPTIBLE), and they are linked to the locations within the attributive paths such as the DOMAIN OF CHARACTER AND BEHAVIOUR [...], the DOMAIN OF MORALITY [...], the DOMAIN OF SEXUAL ACTIVITY [...], the DOMAIN OF ABUSE [...] and the DOMAIN OF PROFESSION [...]. Significantly, in such

2 However, while talking about FOoDSTUFFs in the context of sexuality it is worth mentioning that meat-based metaphorical extensions are by no means restricted to the female kind. The English data has recently been discussed in extenso by Kleparski (2012: 43-49) who observes that the meaning of meat, which in English slang is used in the sense 'a sexual partner', provides the basis for the rise of novel metaphorical formations. And so, for example, the human-specific sense of meat is echoed in the semantics of such compounds as meat markets or meat racks, which are used in reference to bars for singles where one can find - so to speak - someone for sexual consumption. What is more, we have traced the of-phrase a bit of meat standing for sexual intercourse or a prostitute. Finally, such compounds as fresh meat, hot meat and raw meat may be used in reference to 'prostitute' or to 'vagina'. 
cases as, for example, tart and cake the element (YOUNG) specifiable for the DOMAIN OF AGE normally comes into play.

\subsection{Foodsemic transfers targeted at the microcategory FEMALE BREASTS ${ }^{3}$}

We have taken a further step by analyzing those foodsemic transfers that are targeted not only at the macrocategory FEMALE HUMAN BEING, but also those in which the microcategory FEMALE BODY PARTS is the target. To be more specific, we shall focus on the body of figurative senses that are linked secondarily to the microcategory FEMALE BREASTS.

Table 3: FOODSTUFFS for FEMALE BREASTS

\begin{tabular}{|c|c|c|c|}
\hline & Lexical item & Sense & Examples of usage contexts or source \\
\hline 1. & brownies & 'female breasts' & $\begin{array}{l}\text { Wow, look at her brownies. They look so delicious. } \\
\text { Urban Dictionary, Concise New Partridge Dictionary of Slang and } \\
\text { Unconventional English }\end{array}$ \\
\hline 2. & cakes & 'female breasts' & Urban Dictionary \\
\hline 3. & cupcakes & 'female breasts' & $\begin{array}{l}\text { Concise New Partridge Dictionary of Slang and Unconventional } \\
\text { English, The Routledge Dictionary of Modern American Slang and } \\
\text { Unconventional English, Urban Dictionary, Urban Dictionary }\end{array}$ \\
\hline 4. & muffins & 'small female breasts' & Green's Dictionary of Slang \\
\hline 5. & apples & 'female breasts' & $\begin{array}{l}\text { Concise New Partridge Dictionary of Slang and Unconventional } \\
\text { English, Urban Dictionary, Green's Dictionary of Slang }\end{array}$ \\
\hline 6. & coconuts & 'female breasts' & Urban Dictionary, Green's Dictionary of Slang \\
\hline 7. & grapes & 'female breasts' & $\begin{array}{l}\text { Concise New Partridge Dictionary of Slang and Unconventional } \\
\text { English, Urban Dictionary, Green's Dictionary of Slang }\end{array}$ \\
\hline 8. & grapefruits & 'largefemalebreasts' & $\begin{array}{l}\text { Concise New Partridge Dictionary of Slang and Unconventional } \\
\text { English, Urban Dictionary, Green's Dictionary of Slang }\end{array}$ \\
\hline 9. & lemons & 'female breasts' & Urban Dictionary, Green's Dictionary of Slang \\
\hline 10. & mangoes & 'female breasts' & Urban Dictionary, Green's Dictionary of Slang \\
\hline 11. & melons & 'large female breasts' & $\begin{array}{l}\text { Concise New Partridge Dictionary of Slang and Unconventional } \\
\text { English, Urban Dictionary, Green's Dictionary of Slang }\end{array}$ \\
\hline 12. & pumpkins & 'large female breasts' & Urban Dictionary, Green's Dictionary of Slang \\
\hline 13. & watermelons & 'large female breasts' & $\begin{array}{l}\text { Concise New Partridge Dictionary of Slang and Unconventional } \\
\text { English, The Routledge Dictionary of Modern American Slang and } \\
\text { Unconventional English, Urban Dictionary, Urban Dictionary, } \\
\text { Green's Dictionary of Slang }\end{array}$ \\
\hline 14. & chestnuts & 'small female breasts' & $\begin{array}{l}\text { Concise New Partridge Dictionary of Slang and Unconventional } \\
\text { English, Urban Dictionary, Green's Dictionary of Slang }\end{array}$ \\
\hline 15. & baconbits & 'female breasts' & $\begin{array}{l}\text { Concise New Partridge Dictionary of Slang and Unconventional } \\
\text { English, Urban Dictionary }\end{array}$ \\
\hline
\end{tabular}

3 Obviously, the foodsemic view of female parts of the body is in no way restricted to female breasts. As shown by Kowalczyk (2015b) the foodsemic metaphor has pervaded the conceptual category FEMALE PRIVY PARTS. The following lexical items convey the meaning: 'female privy parts': bun, cookie, cake hole, candy, beaver pie, bread, golden doughnut, jelly roll, muffin, pie, sugar dish, honey box, honey pot, apple, apricot, cherry, peach, bean, cabbage, cauliflower, bacon rashers, beef, beef curtains,(vertical) bacon sandwich, meat, meat curtains, meat seat, mutton, cup of tea, jelly box, juice box, lunch-box, jelly, fish, oyster. 


\begin{tabular}{lll}
\hline 17. friedeggs & 'small female breasts' & $\begin{array}{l}\text { Concise New Partridge Dictionary of Slang and Unconventional } \\
\text { English, Urban Dictionary, Green's Dictionary of Slang }\end{array}$ \\
18. heavy cream & 'large female breasts' & $\begin{array}{l}\text { Concise New Partridge Dictionary of Slang and Unconventional } \\
\text { English, The Routledge Dictionary of Modern American Slang and } \\
\end{array}$ \\
& & Unconventional English, Urban Dictionary \\
\hline
\end{tabular}

As far as the morphological status of lexical items linked to the conceptual microcategory FEMALE BREASTS is concerned, it is notable that the majority of them are simple words (cf. apples, brownies, cakes, coconuts, chestnuts, cupcakes, grapefruits, grapes, lemons, mangoes, melons, pumpkins, watermelons). Three of them, however, are complex nouns (bacon bits, heavy cream, fried eggs).

When analyzing the cases of foodsemic transfers targeted at the category FEMALE BREASTS, it is striking that the majority of examples are chiefly fruit names (apples, grapefruits, grapes, lemons, mangoes, melons, watermelons). Still, there are a few words for sweet food items (brownies, cakes, cupcakes), and there is merely one instance of a meat-related word (bacon bits). Earlier, it was stated that terms for meat products play a special role in the mechanism of metaphorical transfers and that they constitute a relatively numerous group of cases of foodsemic developments.

The conclusion is that the majority of cases of foodsemic transfer related to the category FEMALE BREASTS are connected with the attributive value $<$ SWEET $>$. Consequently, the transfers listed in Table 3 above may be said to have been conditioned by the presence of the attributive value $<$ SWEET $>$ which is presupposed by the conceptual dimension of (TASTE). Extra-linguistically, fruits are generally sweet and they evoke pleasing connotations. Hence, we may conceive of the schema $<$ SWEETNESS PERCEIVED AS POSITIVE $>$. However, one can justifiably argue that in a number of cases the DOMAIN OF SHAPE [...] may play a vital role in the rise of foodsemic transfers, such as grapefruits, mangoes, melons, watermelons used in a sense 'female breasts'. We observe that transfers in this category are conditioned by conceptual dimensions, such as the DOMAIN OF SHAPE [...] and the DOMAIN OF SIZE [...], due to the evident visual resemblances. Such resemblances are evident in metaphorical transfers of foodrelated nouns such as apples, coconuts, chestnuts, grapefruits, grapes, mangoes, melons, pumpkins, watermelons where the attributive value $<\mathrm{ROUNDISH}>$ is projected onto the qualities of female breasts. Similarly, various attributive values presupposed by the DOMAIN OF SIZE [...], such as $<$ LARGE $>$, $<$ AVERAGE $>,<$ BIG $>$ or $<$ SMALL $>$, are transferred onto the size of female breasts, and thus terms like grapefruits, melons, watermelons and pumpkins stand for 'large breasts', those for average size fruits, like apples, coconuts, grapes, lemons and mangoes stand metaphorically for average-size breasts, and those like chestnuts serve to encode the sense 'small breasts', whereas fried eggs, for example, stand for small breasts and a flat female chest. Possible paths of development operating here involve, starting with the most general one $<$ FEMALE BREASTS ARE FOOD ITEMS>, <FEMALE BREASTS ARE FRUITS > and $<$ FEMALE BREASTS ARE SWEET BAKERY PRODUCTS $>$.

In every community, there are issues and topics that people are not very eager to talk about in a direct and straightforward manner, and the impact of those subjects and topics that come to be affected by political correctness is growing very fast. For instance, we avoid topics such as 
death, disability and sexual intercourse, which are treated either as taboo subjects or are discussed in you know what terms. To put it simply, there is a ban placed on certain objects and words that one does not dare to pronounce because their very mention may be treated as embarrassing or inviting trouble. Current research shows that there are a number of tools that serve to avoid taboo. We put to use euphemisms to get rid of banned words, to express the embarrassing topics with milder, more delicate vocabulary items. There is a close relationship between euphemisms and metaphors. Since a metaphor is a highly productive mechanism used unconsciously to talk about issues that are difficult to put into words, people resolve to use them eagerly. It is a fact that it is sometimes easier to implement metaphors as they emerge from the social or cultural experiences people share, and they are loaded with meanings that are rooted deeply in our perception of the outer world.

\section{Conclusions}

In this paper, an attempt has been made to show a panorama of foodsemic transfers, which are part and parcel of natural languages. One may formulate, if not rules, then at least certain generalizations based on the nature of the data given above. First of all, one may say that the figurative extensions of words connected with food and food consumption in the majority of cases relate metaphorically to the conceptual category HUMAN BEING, with its various conceptual spheres, such as [APPEARANCE], [MENTAL CAPACITIES] and [SEXUAL ORIENTATION].

The evidence adduced indicates that numerous foodsemy-based metaphorical transfers are closely connected with extra-linguistic conditions; the productivity of a given foodsemic type of metaphorical transfer is frequently triggered by extra-linguistic knowledge, and - in particular - familiarity with a certain type of food. Additionally, the material scrutinized shows a substantial number of euphemistic developments that serve to encode taboo terms connected with sexuality. Those words that are connected with moral issues or sexuality are frequently substituted by euphemistic equivalents that are more acceptable and this is evidenced by the use of tart, tartlet, mutton, sandwich, crumpet, meat, all of which serve to convey the sense immoral woman'. A substantial number of transfers is restricted to informal contexts, and - in particular - to highly colloquial and slang usage. As regards psychological considerations and social attitudes, language users feel a certain urge to use euphemistic expressions.

The majority of foodsemic developments are based on attributive features and sensory experiences related to the DOMAIN OF TASTE [...], namely cheesecake, cupcake, arm candy, cookie, cream puff, sweet meat, biscuit, honey-bunny, sugar pie, sugar baby, shoulder candy, peach, all of which have positive connotations and stand for 'young, attractive female'. Therefore, it can be generalized that sweet foodstuffs often equal to and come to represent conceptually female attractiveness. However, not all lexical items referring to sweet bakery products underwent this path of metaphorical development, but rather they have become terms of endearment. The two lexical items tart and tartlet underwent a different meaning shift. In these two cases female sweetness seems to be perceived from a purely male point of view as a sexual object as the two words are used in reference to 'prostitute'. 
Another observation pertains to the register value of vocabulary items that are products of foodsemic transfer: a substantial number of foodsemically transferred senses are restricted to informal contexts, and - in particular - to very colloquial language and slang usage. All in all, the conceptual picture of a woman that emerges from the corpus of data is in no way homogenous, as there are a number of derogatory terms (e.g. tart, tartlet, meat, veal or mutton), but - at the same time - there are numerous terms of endearment (e.g. cupcake, sugar pie, sugar baby, shoulder candy or biscuit), so one is somewhat justified in speaking of the lexical love-hate proportion. At the same time, many foodsemic figurative extensions are based on attributive features and sensory experiences related to the DOMAIN OF TASTE [...], as evidenced in bun, cake, cupcake, cookie, brownie, pie, golden doughnut, muffin, candy, apple and apricot which reveal that sweet foodstuffs are often equated with FEMALE HUMAN BEING and FEMALE BODY PARTS. Furthermore, it is indicated that the schema <SWEETNESS PERCEIVED AS POSITIVE $>$ is the basis for numerous transfers of vocabulary items referring to FEMALE BREASTS.

\section{References}

Cutierrez-Rivas C. 2011. Women as food in Hispanic cultural metaphors. An Online Feminist Journal 3: 6-20, www.academist.org/wp-content/uploads/2010/06/030302Gutierrez-Rivas_WomenasFood.pdf

Cymbalista, P. 2009. Do you know what you eat? The phenomenon of foodsemy. In G. A. Kleparski, R. Kiełtyka, P. Cymbalista, and K. Pytel (eds.), In Medias Res. Studia Resoviensia in Lingua et Litteris, 9-29. Rzeszów: Wydawnictwo Promar.

Cymbalista, P., and G. A. Kleparski. 2013. From Michael Breal to Dirk Geeraerts. Towards the main issues in diachronic lexical semantics. Jarosław: Wydawnictwo Państwowej Wyższej Szkoły Techniczno-Ekonomicznej im. Ks. Bronisława Markiewicza w Jarosławiu.

Geeraerts, D. 2010. Theories of lexical semantics. Oxford: Oxford University Press.

Grygiel, M. 2008. From semantic change to conceptual blending: English historical near-synonyms of MAN/MALE HUMAN BEING. Rzeszów: Wydawnictwo UR.

Kiełtyka, R. 2009. Zoosemy as a ubiquitous cognitive mechanism. In G. A. Kleparski, R. Kiełtyka, P. Cymbalista, K. Pytel (eds.), In Medias Res. Studia Resoviensia in Lingua et Litteris, 41-56. Rzeszów: Wydawnictwo Promar.

Kiełtyka R., and G. A. Kleparski. 2013. The rudiments of the history of English. Rzeszów: Wydawnictwo Uniwersytetu Rzeszowskiego.

Kleparski G. A.1990. Semantic change in English. A study of evaluative developments in the domain of humans. Lublin: Redakcja Wydawnictw KUL.

Kleparski G. A. 1997. Theory and practice of historical semantics: the case of Middle English and Early Modern English synonyms of GIRL/YOUNG WOMAN. Lublin: Redakcja Wydawnictw KUL.

Kleparski, G. A. 2008. Dolce torta, dolce Angelina: Romance foodsemy with Italian accent. In G. A. Kleparski, and A. Uberman (eds.), Galicia Studies in Language, Literature and Culture. With Special Reference to English and Diachronic Semantics, 33-39. Chełm: Wydawnictwo TAWA.

Kleparski, G. A. 2012. The dark side of foodsemy: On extralinguistically conditioned wammel syndrome. In B. Kopecka, M. Pikor-Niedziałek, and A. Uberman (eds.), Galicia Studies in Language. Historical Semantics Brought to the Fore, 43-62. Chełm: Wydawnictwo TAWA.

Kowalczyk, A. Z. 2015a. The scope of foodsemic developments affecting conceptual category HUMAN BEING: the case of ATTRACTIVE/IMMORAL FEMALE HUMAN BEING. In G. A. Kleparski, J. Wesól, and A. Włodarczyk-Stachurska (eds.), Galicia Studies in Language. With Historical Semantics Foregrounded, 66-75. Chełm: Wydawnictwo TAWA. 
Kowalczyk, A. Z. 2015b. On the projection of FOODSTUFFS on the macrocategory BODY PARTS. TOKEN. A Journal of English Linguistics 4: 129-143.

Kövecses, Z. 2000. Metaphor and emotion: language, culture, and body in human feeling. Cambridge: Cambridge University Press.

Krzeszowski, T. 1991. Metaphor-metaphorization-cognition. Biuletyn Polskiego Towarzystwa Jezykoznawczego XLIII-XLV: 83-95.

Krzeszowski, T. 2003. Jeszcze słów kilka o wartościach, schematach i metaforach. In J. Bartmiński (ed.), Język w kregu wartości, 35-41. Lublin: UMCS.

Lakoff, G. 1987. Women, fire and dangerous things. Chicago and London: University of Chicago Press.

Lakoff, G. 1993. A contemporary theory of metaphor. In A. Ortony (ed.), Metaphor and thought, 151-202. Cambridge: Cambridge University Press.

Lakoff G., and M. Johnson. 1980. Metaphors we live by. Chicago: University of Chicago Press.

Lakoff, G., and M. Turner. 1989. More than cool reason: a field guide to poetic metaphor. Chicago: University of Chicago Press.

Lagacker, R. 1987. Foundations of cognitive grammar. Stanford: Stanford University Press.

Langacker, R. 2000. Grammar and conceptualization. Berlin, New York: Mouton de Gruyter.

Mańczak-Wohlfeld, E. 1992. Analiza zapożyczeń angielskich w języku polskim. Kraków: Wydawnictwo UJ.

Ruiz de Mendoza, F. J. 1997. Metaphor, metonymy and conceptual interaction. https://www.researchgate.net/publication/28049874_Metaphor_metonymy_and_conceptual_interaction

Szwedek, A. 2000. The ontology of metaphors: the sense of touch in language formation. Scripta Periodica 4: 193199.

Szwedek, A. 2004. Objectification in metaphorical processes - Some philosophical issues. Lingua Posnanensis 46: 121-129.

\section{Dictionaries and encyclopaedias}

Dalzell, T., and T. Victor (eds.). 2007. Concise New Partridge Dictionary of Slang and Unconventional English. New York: Routledge. Taylor and Francis Group.

Dalzell, T. (ed.). 2008. The Routledge Dictionary of Modern American Slang and Unconventional English. New York: Routledge. Taylor and Francis Group.

Dalzell, T. 1998. The Slang of Sin. Springfield: Merrian-Webster, Incorporated.

Glazier, S. 1997. Word Menu. New York: Ballantine Books.

Green, J. 2017. Green's Dictionary of Slang. https:/greendictofslang.com/

Oxford English Dictionary. 1976. Oxford: Oxford University Press.

The Probert Encyclopedia of Slang. 2004. www.probert-encyclopaedia.co.uk/slang.htm

Rees, N. 2002. Cassell's Dictionary of Word and Phrase Origins. London: Cassell.

\section{Netography}

www.urbandictionary.com

www.dictionary.reference.com

www.onlineslangdictionary.com 